\title{
Evaluation of pH of Facial Cleansers Available in the Bangladeshi Market
}

\author{
Paroma Arefin $^{1 *}$, Tamjid-Us-Sakib ${ }^{2}$, Md. Shehan Habib ${ }^{3}$, Trissa Saha ${ }^{1}$ and Farhana Boby ${ }^{1}$ \\ ${ }^{1}$ Bangladesh Council for Scientific and Industrial Research (BCSIR) Laboratories, Rajshahi, Bangladesh \\ ${ }^{2}$ Institute of Mining, Mineralogy \& Metallurgy (IMMM), Bangladesh Council of Scientific and Industrial Research (BCSIR), Bangladesh \\ ${ }^{3}$ Bangladesh Council for Scientific and Industrial Research (BCSIR) Laboratories, Chittagong, Bangladesh
}

Received Date: February 26, 2020 ; Published Date: March 16, 2020

*Corresponding author: Paroma Arefin, Scientific Officer, Bangladesh Council for Scientific and Industrial Research, Rajshahi, Bangladesh

\begin{abstract}
Facial Cleansers are integral part of daily skin care and widely used for the maintenance of hygiene and cleanliness. Healthy skin $\mathrm{pH}$ range is 5.4-5.9. At this $\mathrm{pH}$, the regular skin bacterial flora is maintained. Facial cleansers with high $\mathrm{pH}$ increase skin $\mathrm{pH}$ resulting in skin dehydration, irritation and alteration in bacterial flora. The majority of facial cleansers available in the Bangladeshi market do not disclose their $\mathrm{pH}$. The skin of Bangladeshi people is becoming dull, rough and dehydrated. The aim of this study was to evaluate the $\mathrm{pH}$ of different brands of facial cleansers available in the Bangladeshi market to get an overview of the effect of these products on skin problems.
\end{abstract}

Keywords: Facial cleansers; pH; Acid mantle

\section{Introduction}

Acid mantle is crucial for healthy skin. Acid mantle is a naturally secreted, thin, protective layer that covers skin. It is composed of oils, lactic acid, amino acids, fatty acids and skin's own natural moisturizing factor [1]. Its $\mathrm{pH}$ is between 4.5 and 5.5 [2]. It assists the normal microbial flora of the skin to build up properly and creates a wall that guards against pathogens and outside irritants, as well as against the skin's internal dehydration. A number of key enzymes involved in the creation and safeguarding of a competent skin barrier are largely impacted by $\mathrm{pH}$. Studies have shown that elevations of $\mathrm{pH}$ in normal skin creates a disturbed barrier, causes increased activity of serine proteases and reduced activities of ceramidegenerating enzymes [1,3].

But acid mantle can be cleaned or scrubbed away, and it can moreover be counterbalanced by cleansers that raise the $\mathrm{pH}$ of skin above 6 [4-6]. A tight squeaky-clean feeling after washing is felt on using facial cleansers above this $\mathrm{pH}$ range. Scrapping acid mantle away can increase the chances of skin damage and infection. The $\mathrm{pH}$ of Facial cleansers varies depending on their composition and even have a $\mathrm{pH}$ range of 9-11, which can make skin dry and make it more vulnerable to bacterial development. The acid mantle takes from 15 minutes to 14 hours to restore itself, depending on how much it's been disrupted or damaged if once damaged [5]. Even use of 'neutral' pH products is not recommended. Because normal flora growth is optimal at acidic $\mathrm{pH}$ levels, but pathogenic bacteria, such as $\mathrm{S}$. aureus, thrive at a neutral pH levels [6]. So, use of products with a pH of 5.5-6.5 is recommended. It is helpful to maintain the skin's acid mantle. Using cleansers in this $\mathrm{pH}$ range is essential in order to maintain hygiene and moisture. If skin care, hygiene and hydration are insufficient, the skin will turn sensitive and dry $[7,8]$. Hence, a broader view of the importance of $\mathrm{pH}$ in relation to function and integrity of the skin is emerging.

\section{Materials and Methods}

The $\mathrm{pH}$ values of facial cleansers vary depending on their formulation and composition. The increase in $\mathrm{pH}$ potentiates skin dryness and poses potential risk of cutaneous reactions. So, we collected facial cleanser samples to check their $\mathrm{pH}$. The samples of facial cleansers were collected from different retail shop and departmental stores of Bangladesh. The sample cleansers of different brands (both Bangladeshi and multinational) were coded before the commencement of the $\mathrm{pH}$ analysis. $\mathrm{pH}$ was measured using $\mathrm{pH}$ meter. The liquid cleansers were weighed at one gram and was made $10 \%$ cleansing solutions in tap water in order to resemble the actual usage condition. The $\mathrm{pH}$ of tap water was measured 7.02. The $\mathrm{pH}$ was measured using 
a pH meter (Thermo Scientific Orion 2 Star pH/ conductivity benchtop meter Thermo Scientific, Beverly, MA, USA). The level of uncertainty was \pm 0.07 . The $\mathrm{pH}$ of each sample was measured thrice to obtain an average value [9-12].

\section{Results and Discussion}

Of the 65 samples of facial cleansers tested, 4 cleansers had a $\mathrm{pH}$ within the range of 3.01 to 4 . Among these four cleansers, two was blackhead clearing facewash and two was daily face wash. Six facial cleansers had pH between 4.01-5. Among these, three were antiseptic face wash, two were mild liquid cleansers and one was daily use face wash. Only five face washes were in the range of pH 5.01-6. Among these, two were ayurvedic purifying facial cleansers, two were fairness facial cleansers and one was ayurvedic fairness face wash. Eight of the 65 samples had $\mathrm{pH}$ in the range of 6.01 to 7 . Of these, two were acne oil control facial cleansers, four were herbal face washes and two were activated charcoal face wash. Ten samples had pH between 7.01- 8. Of these, six cleansers were anti acne face wash and rest were facial cleansers. Twelve samples had $\mathrm{pH}$ in the range of 8.01-9. Among these, seven were fairness facial cleansers and five were antiacne face washes. Unexpectedly, twenty samples had $\mathrm{pH}$ between 9.01-10. Five of them were men facial cleansers, one was anti acne for men, three were clay face wash, two were charcoal face wash, one was white clay anti acne face wash, one was pollution removing facial wash, three were scrub facial washes and four were brightening facial cleansers.

The results of the study revealed that only $7.69 \%$ of the facial cleansers tested had a pH in the range of 5.01-6.0 .12.31\% cleansers had a neutral $\mathrm{pH}$. The rest of the products have alkaline $\mathrm{pH}$. These are not also $\mathrm{pH}$ labeled. But alarmingly, $30.77 \%$ cleansers were in very alkaline $\mathrm{pH}$ range of 9.01-10.00. It is observed that man face washes and fairness cleansers have highest $\mathrm{pH}$ levels. Herbal face washes usually have slightly acidic or neutral $\mathrm{pH}$.

Table 1: Total number and percentage of facial cleansers samples in the various $\mathrm{pH}$ range. $\mathrm{pH}$ : Potential of hydrogen.

\begin{tabular}{|c|c|c|}
\hline $\mathbf{p H}$ Range & No. of Facial Cleansers Samples in the pH Range & Percentage of Facial Cleansers Samples in the pH Range (\%) \\
\hline $3.01-4.00$ & 4 & 6.15 \\
\hline $4.01-5.00$ & 6 & 9.23 \\
\hline $5.01-6.00$ & 5 & 7.69 \\
\hline $6.01-7.00$ & 8 & 12.31 \\
\hline $7.01-8.00$ & 10 & 15.38 \\
\hline $8.01-9.00$ & 12 & 18.46 \\
\hline $9.01-10.00$ & 20 & 30.77 \\
\hline
\end{tabular}

\section{Conclusion}

The facial cleansers commonly used by the population at large have a $\mathrm{pH}$ outside the range of normal skin $\mathrm{pH}$ values. As the $\mathrm{pH}$ has a vital role on skin health, hygiene and integrity, so the facial cleansers should be chosen carefully. The manufacturers must label the actual $\mathrm{pH}$ of the facial cleansers so that the $\mathrm{pH}$ remains in control.

\section{References}

1. Ali S, Yosipovitch G (2013) Skin pH: From Basic Science to Basic Skin Care. ActaDermato-Venereologica 93(3): 261-267.

2. Schreml S, Szeimies RM, Karrer S, Heinlin J, Landthaler M, et al. (2010) The impact of the $\mathrm{pH}$ value on skin integrity and cutaneous wound healing. Journal of the European Academy of Dermatology and Venereology 24(4): 373-378.

3. Bigliardi PL (2018) Role of Skin pH in Psoriasis. Current Problems in Dermatology 108-114.

4. https://www.leti.com/dermatologia/en/skin-s-acid-mantle-and-phof-5-5_96316

5. Schmid-Wendtner MH, Korting HC (2006) The pH of the Skin Surface and Its Impact on the Barrier Function. Skin Pharmacology and Physiology 19(6): 296-302.
6. https://ecologyskincare.com/what-is-your-acid-mantle-and-why-isit-so-important-for-skin-health

7. Tarun J, Susan V, Susan J, Suria J, Criton S (2014) Evaluation of pH of bathing soaps and shampoos for skin and hair care. Indian J Dermatol 59(5): 442 .

8. https://ecologyskincare.com/what-is-your-acid-mantle-and-why-isit-so-important-for-skin-health

9. Blaak J, Staib P (2018) The Relation of $\mathrm{pH}$ and Skin Cleansing. Current Problems in Dermatology 54: 132-142.

10. Kulthanan K, Maneeprasopchoke P, Varothai S, Nuchkull P (2014) The pH of antiseptic cleansers. Asia Pac Allergy 4(1): 32.

11. Eo J, Seo YK, Baek JH, Choi AR, Shin MK, et al. (2015) Facial skin physiology recovery kinetics during 180 min post-washing with a cleanser. Skin Research and Technology 22(2): 148-151.

12. Kulthanan K, Nuchkull P, Varothai S, Pluetrattanabha N (2015) The pH of skin cleansers for acne. Indian J Dermatol Venereol Leprol 81(2): 181. 
This work is licensed under Creative Commons Attribution 4.0 License

DOI: 10.19080/NAPDD.2019.05.555660
Your next submission with Juniper Publishers will reach you the below assets

- Quality Editorial service

- Swift Peer Review

- Reprints availability

- E-prints Service

- Manuscript Podcast for convenient understanding

- Global attainment for your research

- Manuscript accessibility in different formats

( Pdf, E-pub, Full Text, Audio)

- Unceasing customer service

Track the below URL for one-step submission https://juniperpublishers.com/online-submission.php 